\title{
Detection of Coordinate Based Accident-Prone Areas on Road Surface using Machine Learning Methods
}

\author{
Anitha Kumari Dara ${ }^{1}$ and Dr. A. Govardhan ${ }^{2}$ \\ ${ }^{1}$ Research Scholar in CSE Department, JNTUH, Hyderabad, Telangana, INDIA \\ ${ }^{2}$ Professor in CSE Department, JNTUH, Hyderabad, Telangana, INDIA \\ 19anithakumaridara@gmail.com, ${ }^{2}$ govardhan_cse@jntuh.ac.in
}

\begin{abstract}
The growth in the road networks in India and other developing countries have influenced the growth in transport industry and other industries, which depends on the road network for operations. The industries such as postal services or mover services have influenced the similar growths in these industries as well. However, the dependency of these industries is high on the road surface conditions and any deviation on the road surface conditions can also influence the performance of the services provided by the mentioned services. Nonetheless, the conditions of the road surface are one of the prime factors for road safety and number of evidences are found, which are discussed in subsequent sections of this work, that the bad road surface conditions are increasing the road accidents. Several parallel research attempts are deployed in order to find out, the regions where the road surface conditions are not proper, and the traffic density is higher. Nevertheless, outcomes of these parallel works are highly criticised due to the lack of accuracy in detection of the road surface defects, detection of accurate location of the defects and detection of the traffic density data from various sources. Thus, this work proposes a novel framework for detection of the road defect and further mapping to the spatial data coordinates resulting into the detection of the accident-prone zones or accident affinities of the roads. This work deploys a self-adjusting parametric coefficient-based regression model for detection of the risk factors of the road defects and in the other hand, extracts the traffic density of the road regions and further maps the accident affinities. This work outcomes into $97.69 \%$ accurate detection of the road accident affinity and demonstrates less complexity compared with the other parallel research outcomes.
\end{abstract}

Keywords: Correlation, Adaptive, Location Dependent, Accident Possibility Prediction, Regression.

\section{INTRODUCTION}

The possibilities of the encountering an accident is rare and detecting the possibilities of encountering an accident is even rarer. However, detection of the possibilities of encountering an accident can be very significant for various purposes such as making medical support available, generating the safe tracks for transportations and many more. Accident prone regions depends primarily on two aspects as road surface conditions and the traffic density. The first category must be detected, and the second category of the data must be fetched in order to detect the possibilities of encountering the accidents. The detected possible values for encountering the accident can lead to the avoidance of the accident for saving valuable human life.

In the recent past, a good number of parallel research attempts were made in order to detect the possibilities of the road accidents for making preventive measures and actions. Nevertheless, the outcomes of these parallel researches are highly criticized either for not being very accurate or for being highly time complex.

Majority of the parallel research outcomes have focused on the traffic data more rather than the road surface data as sequence of the events. This led to the lesser focus on the external influencing parameters such as road or weather conditions. Henceforth, motivated by the demand of the current research trends, this work formulates the following objectives for the research.

- Propose a machine learning method to predict the higher accident-prone regions

- Propose another machine learning method for avoidance of the accidents

The rest of the work is organized such that, in the Section - II, the parallel research outcomes are discussed, in Section - III, the mathematical model for the proposed solutions is discussed, in the Section - IV, the proposed algorithms are furnished, in the Section $-\mathrm{V}$, the results obtained from the proposed framework is elaborated, in the Section - VI, the comparative analysis with the 
parallel research outcomes are discussed, in the Section VII the final research conclusion is presented.

\section{PARALLEL RESEARCH OUTCOME}

In order to formulate the problem in a better way, the understanding of the parallel research outcomes is highly crucial. Henceforth, in this section of the work, the parallel research outcomes are discussed.

As discussed in the previous section of this work, majority of the parallel research works have focused on the traffic pattern and mostly ignored the external influencing factors. In the same direction the work by Cai Y. et al. [1] have showcased the possibilities of traffic pattern modelling using the trajectories of the vehicles. This work is also criticised for being on the higher side of the framework complexity. Also, the work by Wang H. et al. [2] have aimed for similar outcomes with the reduced complexity of the model and aimed for detection of the next action on the event-based sequence of the modelling. In the other hand, additional to the previous two benefits, the work by Wang G. [3] have showcased that, the detection of the traffic sign is also an added information, that can help in predicting the possibilities of road accidents. This work is criticised highly for the higher complexity of the framework for making it adaptive for different road conditions. The bottlenecks of this work were addressed in the work by Khalid S. [4].

The other direction of this parallel research outcome has demonstrated that the information of the driving personals can also help in predicting the accident possibilities as showcased in the work by Yang A.Y. [5].

The mainstream research outcomes focus on the vehicle information such as distances between vehicles and the speed of the nearing vehicles. The work by Dong Z.S. [6] have showcased the optimal use of the sensors for these purposes. This work is widely accepted by many other parallel research attempts as the similar outcomes where produced by Mahmood Z. [7] for making the parking automation and avoidance of collisions during tight parking spaces. Nonetheless, the demand for using the machine learning methods for detection of the accident possibilities with the sense of severity analysis is the most effective way for achieving higher performance with lower complexity of the framework, which is also confirmed by many researchers as one of the notable outcome by Nguyen H. [8].

Henceforth, in the next section of the work, the problem solution, identified in this section of the work, is presented using the mathematical model.

\section{MATHEMATICAL MODEL}

After the detailed understanding of the gaps in the parallel research works, in this section of the work, the proposed solution is mathematically modelled.

Firstly, assuming that the complete dataset is identified as DS[] and each and every tuple is denoted as $\mathrm{D}_{\mathrm{X}}$, then for a total number of $\mathrm{n}$ record, the relationship can be formulated as,

$$
D S[]=\sum_{i=1}^{n} D_{i}
$$

Secondly, two parameters in the dataset are the coordinate parameters as $(\mathrm{X}, \mathrm{Y})$. Thus, the from the initial set of parameters, these two parameters must be kept aside for the next phase of calculations. Henceforth, the new reduced dataset is assumed as DS'[] for a total $m$ number of elements.

Further, a new class variable must be added to the existing dataset, as $\mathrm{C}_{\mathrm{X}}$, for making the regression model to work. The relation can be formulated as,

$$
C_{X}=\beta_{0}+\beta_{1} . D S^{\prime}[1]+\beta_{2} . D S^{\prime}[2]+\ldots .+\beta_{m} . D S^{\prime}[m](\mathrm{Eq} .2)
$$

Where, the correlation coefficients are identified as $\beta_{X}$.

The correlation coefficients are calculated based on the inter-relation of the member of the tuples or the other attributes as,

$$
\beta_{X}=\frac{\sum_{i=1}^{m} D S^{\prime}[i]}{\sum_{i=1}^{m} D S^{\prime}[i+1]}
$$

Where, "i" denotes subsequent attribute indexes from the datasets.

Further, the class variable $\mathrm{C}_{\mathrm{X}}$, is used to categorize the defects into four different classes, as,

$$
C_{X}=<\text { NoDefect, Patch, Crack, Pothole }>
$$

Finally, with the class variable and coordinate valuables are merged together to form the final dataset as DS', [], as,

$$
D S^{\prime \prime}[]=<C_{X}, X, Y>
$$

And, with the highest density of the defects, the most accident-prone zones are identified. 
Table 1: Firstly, the complete dataset is furnished here for initial visualization.

\begin{tabular}{|c|c|c|c|c|c|c|c|c|c|c|}
\hline $\begin{array}{c}\text { Datase } \\
t \text { ID }\end{array}$ & $\begin{array}{c}\text { Long } \\
\text { Slope } \\
\text { (Degree } \\
\text { ) }\end{array}$ & $\begin{array}{c}\text { Perpendicula } \\
\text { r Slope } \\
\text { (Degree) }\end{array}$ & $\begin{array}{c}\text { Defect } \\
\text { Numbe } \\
\text { r }\end{array}$ & $\begin{array}{c}\text { Distanc } \\
\text { e } \\
\text { betwee } \\
\text { n the } \\
\text { Defects } \\
\text { (cm) }\end{array}$ & $\begin{array}{c}\text { Dept } \\
\text { h } \\
(\mathrm{cm})\end{array}$ & $\begin{array}{l}\text { Averag } \\
\text { e } \\
\text { Width } \\
\text { (cm) }\end{array}$ & $\begin{array}{l}\text { Area } \\
\left(\mathrm{cm}^{3}\right)\end{array}$ & Latitude & Longitude & $\begin{array}{c}\text { Severity } \\
\text { of the } \\
\text { Defect }\end{array}$ \\
\hline 1 & -0.21 & 4.71 & 1 & 250.46 & $\begin{array}{c}122.2 \\
3 \\
\end{array}$ & 88.89 & 22263 & $\begin{array}{c}17.7088565 \\
9 \\
\end{array}$ & $\begin{array}{c}77.4062933 \\
9 \\
\end{array}$ & None \\
\hline 2 & 0.33 & -3 & 1 & 199.22 & 65.21 & 43.06 & 8579 & 17.5284391 & $\begin{array}{c}77.4832292 \\
8 \\
\end{array}$ & None \\
\hline 3 & -0.21 & 4.7 & 1 & 976.34 & $\begin{array}{c}266.0 \\
6 \\
\end{array}$ & 241.2 & $\begin{array}{c}23549 \\
4 \\
\end{array}$ & $\begin{array}{c}17.6632175 \\
7 \\
\end{array}$ & $\begin{array}{c}77.4145125 \\
2 \\
\end{array}$ & None \\
\hline 4 & -0.3 & 3.29 & 1 & 402.39 & $\begin{array}{c}189.5 \\
3 \\
\end{array}$ & 49.69 & 19994 & $\begin{array}{c}17.6813259 \\
6 \\
\end{array}$ & $\begin{array}{c}77.4476617 \\
3 \\
\end{array}$ & Low \\
\hline 4 & -0.15 & 6.78 & 2 & 246.64 & $\begin{array}{c}182.1 \\
8 \\
\end{array}$ & 36.94 & 9110 & $\begin{array}{c}17.6813259 \\
6 \\
\end{array}$ & $\begin{array}{c}77.4476617 \\
3 \\
\end{array}$ & Low \\
\hline 4 & 0.23 & -4.3 & 3 & 278.23 & $\begin{array}{c}185.5 \\
2 \\
\end{array}$ & 27.47 & 7644 & $\begin{array}{c}17.6813259 \\
6 \\
\end{array}$ & $\begin{array}{c}77.4476617 \\
3 \\
\end{array}$ & Low \\
\hline 5 & 0.65 & -1.54 & 1 & 166.98 & 99.18 & 55.89 & 9333 & $\begin{array}{c}17.6178882 \\
8 \\
\end{array}$ & 77.3871209 & Low \\
\hline 6 & 0.72 & -1.4 & 1 & 907.43 & $\begin{array}{c}648.3 \\
8\end{array}$ & 397.55 & $\begin{array}{c}36074 \\
7\end{array}$ & 17.7781966 & $\begin{array}{c}77.8430089 \\
5 \\
\end{array}$ & $\begin{array}{c}\text { Moderat } \\
\mathrm{e}\end{array}$ \\
\hline 7 & 0.6 & -1.67 & 1 & 602.82 & $\begin{array}{c}692.6 \\
7 \\
\end{array}$ & 167.89 & $\begin{array}{c}10120 \\
8 \\
\end{array}$ & $\begin{array}{c}17.8422149 \\
4 \\
\end{array}$ & $\begin{array}{c}77.7190736 \\
2 \\
\end{array}$ & $\begin{array}{c}\text { Moderat } \\
\mathrm{e}\end{array}$ \\
\hline 7 & 0.78 & -1.28 & 2 & 870.4 & 755 & 308.03 & $\begin{array}{c}26810 \\
5\end{array}$ & $\begin{array}{c}17.8422149 \\
4 \\
\end{array}$ & $\begin{array}{c}77.7190736 \\
2 \\
\end{array}$ & $\begin{array}{c}\text { Moderat } \\
\mathrm{e}\end{array}$ \\
\hline 8 & 0.75 & -1.33 & 1 & 1029.8 & $\begin{array}{c}774.3 \\
6 \\
\end{array}$ & 371.21 & $\begin{array}{c}38227 \\
2 \\
\end{array}$ & $\begin{array}{c}17.7609588 \\
9 \\
\end{array}$ & $\begin{array}{c}77.5645479 \\
5 \\
\end{array}$ & High \\
\hline 9 & 0.17 & -5.97 & 1 & 175.41 & 21.17 & 19.46 & 3413 & $\begin{array}{c}17.6964494 \\
5 \\
\end{array}$ & $\begin{array}{c}77.3606215 \\
3 \\
\end{array}$ & High \\
\hline 10 & 0.45 & -2.23 & 1 & 354.05 & $\begin{array}{c}158.6 \\
8\end{array}$ & 88.54 & 31347 & $\begin{array}{c}17.7013711 \\
2\end{array}$ & $\begin{array}{c}77.8309285 \\
3 \\
\end{array}$ & None \\
\hline
\end{tabular}

The initial dataset is again analysed graphically here [Fig $1]$.

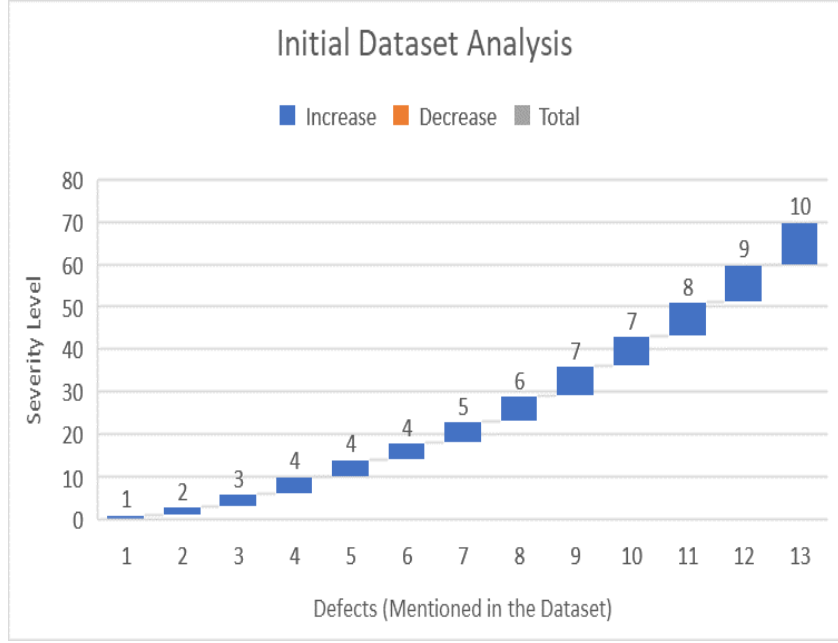

Fig. 1. Initial Dataset Analysis
Secondly, after the removal of the location parameters, the threshold calculation for remaining data attributes are performed and the results are furnished here [Table -2 ].

Table 2: Threshold calculation Results

\begin{tabular}{|c|c|}
\hline Parameter Names & Threshold Calculation Results \\
\hline Long Slope & 0.293076923 \\
\hline Perpendicular Slope & -0.249230769 \\
\hline Defect Number & 1.307692308 \\
\hline $\begin{array}{c}\text { Distance between the } \\
\text { Defects }\end{array}$ & 496.9361538 \\
\hline Depth & 320.0130769 \\
\hline Average Width & 145.8323077 \\
\hline Area & 112269.9231 \\
\hline
\end{tabular}

As the scale differs, maybe one is changing the amplifying intensity of a notional magnifying lens seeing the framework. In purported realizable speculations, the framework at one scale will by and large be believed to comprise of self-comparative duplicates of itself when seen at a littler scope, with various parameters depicting the segments of the framework. The obtained results are also visualized graphically here [Fig -2$]$. 


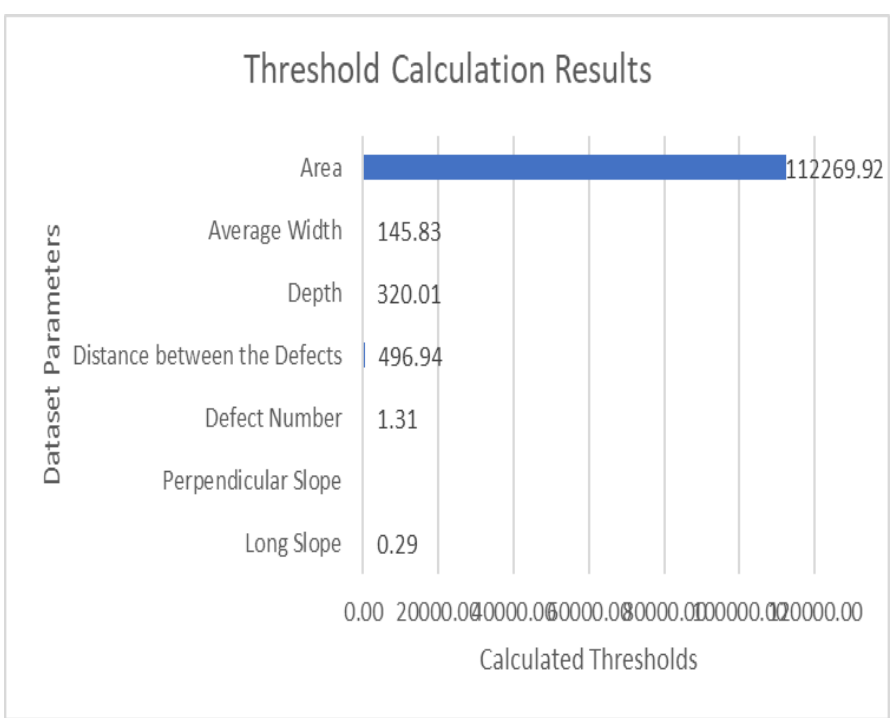

Fig. 2. Threshold Calculation Results

Thirdly, the value for the coefficients are calculated and the obtained results are furnished here [Table -3$]$.

Table 3: Threshold calculation Results

\begin{tabular}{|c|c|c|}
\hline Parameter Names & Coefficients & $\begin{array}{c}\text { Coefficient } \\
\text { Value }\end{array}$ \\
\hline Long Slope & Coefficient. 0 & 0.000 \\
\hline Perpendicular Slope & Coefficient. 1 & -1.176 \\
\hline Defect Number & Coefficient. 2 & -0.191 \\
\hline $\begin{array}{c}\text { Distance between the } \\
\text { Defects }\end{array}$ & Coefficient. 3 & 0.003 \\
\hline Depth & Coefficient. 4 & 1.553 \\
\hline Average Width & Coefficient. 5 & 2.194 \\
\hline Area & Coefficient. 6 & 0.001 \\
\hline
\end{tabular}

The polymorphic relationship coefficient estimates relationship between two arranged unmitigated factors. It's characterized as the gauge of the Pearson relationship coefficient one would acquire if the two factors were estimated on a persistent scale, rather than as requested class factors, and the two consistent factors followed a bivariate typical circulation. At the point when the two factors are dichotomous rather than requested downright, the polymorphic relationship coefficient is known as the metaphoric connection coefficient. The obtained results are also visualized graphically here [Fig - 3].

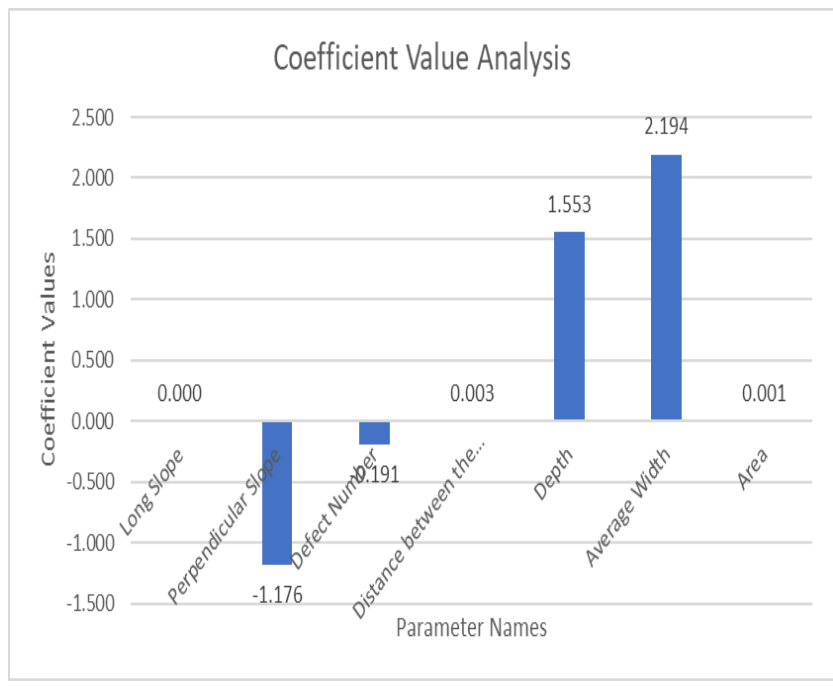

Fig. 3. Coefficients Calculation Results

Fourthly, the Accident Possibility Detection results are furnished here [Table -4$]$.

Table 4: Accident Possibility Detection Results

\begin{tabular}{|c|c|c|c|c|}
\hline $\begin{array}{c}\text { Data } \\
\text { set } \\
\text { ID }\end{array}$ & Latitude & Longitude & $\begin{array}{c}\text { Detected } \\
\text { Defect } \\
\text { Class }\end{array}$ & $\begin{array}{c}\text { Accident } \\
\text { Possibility } \\
\text { Detection }\end{array}$ \\
\hline 1 & 17.70885659 & 77.40629339 & 0 & Clear Road \\
\hline 2 & 17.5284391 & 77.48322928 & 0 & Clear Road \\
\hline 3 & 17.66321757 & 77.41451252 & 1 & Clear Road \\
\hline 4 & 17.68132596 & 77.44766173 & 2 & $\begin{array}{l}\text { Minor } \\
\text { Patches, } \\
\text { Low } \\
\text { Accident } \\
\text { Prune }\end{array}$ \\
\hline 4 & 17.68132596 & 77.44766173 & 2 & $\begin{array}{c}\text { Minor } \\
\text { Patches, } \\
\text { Low } \\
\text { Accident } \\
\text { Prune }\end{array}$ \\
\hline 4 & 17.68132596 & 77.44766173 & 2 & $\begin{array}{l}\text { Minor } \\
\text { Patches, } \\
\text { Low } \\
\text { Accident } \\
\text { Prune }\end{array}$ \\
\hline 5 & 17.61788828 & 77.3871209 & 2 & $\begin{array}{c}\text { Minor } \\
\text { Patches, } \\
\text { Low } \\
\text { Accident } \\
\text { Prune } \\
\end{array}$ \\
\hline 6 & 17.7781966 & 77.84300895 & 4 & $\begin{array}{c}\text { Cracks on } \\
\text { Road, Mid } \\
\text { Accident } \\
\text { Prune } \\
\end{array}$ \\
\hline 7 & 17.84221494 & 77.71907362 & 5 & $\begin{array}{c}\text { Cracks on } \\
\text { Road, Mid } \\
\text { Accident } \\
\text { Prune }\end{array}$ \\
\hline 7 & 17.84221494 & 77.71907362 & 6 & Cracks on \\
\hline
\end{tabular}




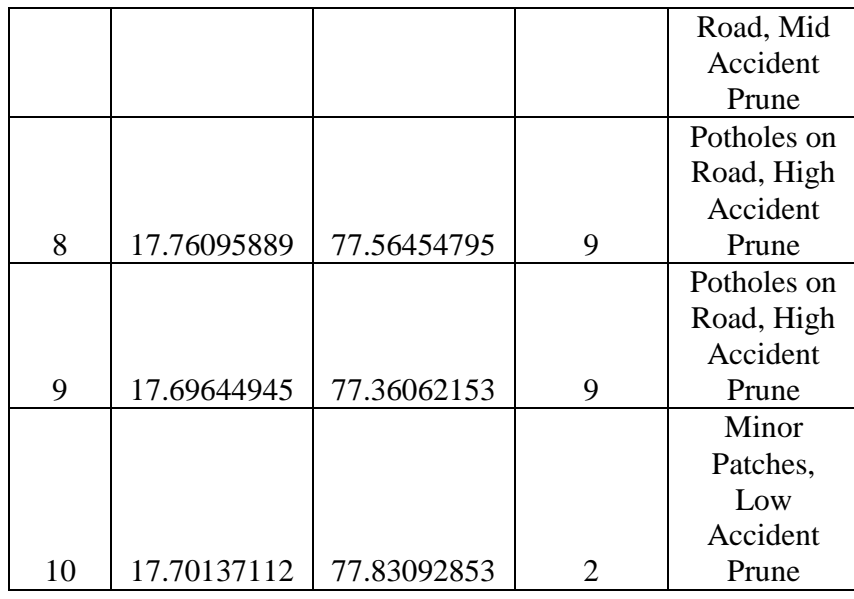

The results are visualized graphically here [Fig - 4].

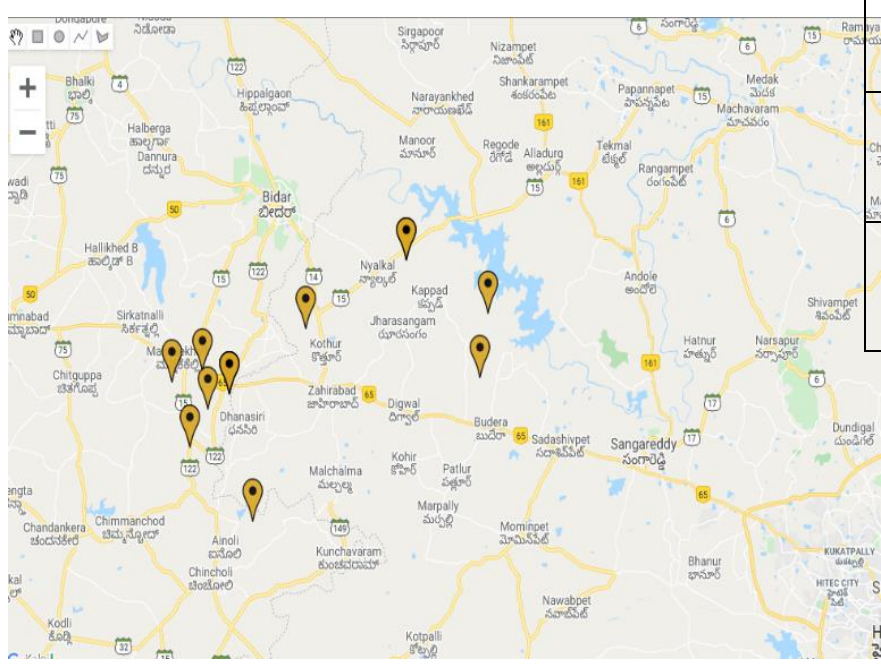

Fig. 4. Accident Possibility Analysis Zones

Finally, the accuracy analysis is carried out and the results are furnished here [Table -5$]$.

Table 5: Accident Possibility Detection Accuracy

\begin{tabular}{|c|c|c|c|c|}
\hline $\begin{array}{c}\text { Dataset } \\
\text { ID }\end{array}$ & $\begin{array}{c}\text { Accident } \\
\text { Possibility } \\
\text { Detection } \\
\text { (Dataset } \\
\text { Results) }\end{array}$ & $\begin{array}{c}\text { Accident } \\
\text { Possibility } \\
\text { Detection } \\
\text { (Proposed } \\
\text { Algorithm } \\
\text { Analysis } \\
\text { Results) }\end{array}$ & $\begin{array}{c}\text { Accuracy } \\
(\%)\end{array}$ & $\begin{array}{c}\text { Overall } \\
\text { Accuracy } \\
(\%)\end{array}$ \\
\hline 1 & None & Clear Road & 100 & \multirow{5}{*}{97.69} \\
\hline 2 & None & Clear Road & 100 & \\
\hline 3 & None & Clear Road & 100 & \\
\hline 4 & Low & $\begin{array}{c}\text { Minor } \\
\text { Patches, Low } \\
\text { Accident } \\
\text { Prune }\end{array}$ & 100 & \\
\hline 4 & Low & $\begin{array}{c}\text { Minor } \\
\text { Patches, Low } \\
\text { Accident } \\
\text { Prune }\end{array}$ & 100 & \\
\hline
\end{tabular}

\begin{tabular}{|c|c|c|c|}
\hline 4 & Low & $\begin{array}{c}\text { Minor } \\
\text { Patches, Low } \\
\text { Accident } \\
\text { Prune }\end{array}$ & 100 \\
\hline 5 & Low & $\begin{array}{c}\text { Minor } \\
\text { Patches, Low } \\
\text { Accident } \\
\text { Prune }\end{array}$ & 100 \\
\hline 6 & Moderate & $\begin{array}{c}\text { Cracks on } \\
\text { Road, Mid } \\
\text { Accident } \\
\text { Prune }\end{array}$ & 100 \\
\hline 7 & Moderate & $\begin{array}{c}\text { Cracks on } \\
\text { Road, Mid } \\
\text { Accident } \\
\text { Prune }\end{array}$ & 100 \\
\hline 7 & Moderate & $\begin{array}{c}\text { Cracks on } \\
\text { Road, Mid } \\
\text { Accident } \\
\text { Prune }\end{array}$ & 100 \\
\hline 8 & High & $\begin{array}{l}\text { Potholes on } \\
\text { Road, High } \\
\text { Accident } \\
\text { Prune }\end{array}$ & 100 \\
\hline 9 & High & $\begin{array}{l}\text { Potholes on } \\
\text { Road, High } \\
\text { Accident } \\
\text { Prune }\end{array}$ & 100 \\
\hline 10 & None & $\begin{array}{c}\text { Minor } \\
\text { Patches, Low } \\
\text { Accident } \\
\text { Prune }\end{array}$ & 70 \\
\hline
\end{tabular}

Henceforth, it is natural to realize that, the proposed method demonstrates significantly high accuracy for the possibility detection of the accidents.

Furthermore, in the next section of the work, the proposed framework is compared with the other parallel research àtcomes.

\section{COMPARATIVE ANALYSIS}

After the detailed analysis of the obtained results, in this section of the work, the parallel research outcomes are compared with the proposed framework, in order to obtain the confidence of being better compared with all other parallel research outcomes [Table -6$]$.

Table 6:Comparative Analysis

\begin{tabular}{|c|c|c|c|}
\hline $\begin{array}{c}\text { Method, } \\
\text { Author \& } \\
\text { Year }\end{array}$ & $\begin{array}{c}\text { Model } \\
\text { Complexity }\end{array}$ & Features & $\begin{array}{c}\text { Accuracy } \\
(\%)\end{array}$ \\
\hline $\begin{array}{c}\text { Trajectory- } \\
\text { based, Y. } \\
\text { Cai, 2015 } \\
{[1]}\end{array}$ & $\mathrm{O}(\mathrm{n} * \mathrm{~m})$ & $\begin{array}{c}\text { Traffic } \\
\text { Surveillance }\end{array}$ & \\
\hline $\begin{array}{c}\text { Dense } \\
\text { Trajectory, } \\
\text { H. Wang, }\end{array}$ & $\mathrm{O}\left(\mathrm{n}^{\mathrm{m}}\right)$ & Action recognition & 91 \\
\hline \multicolumn{2}{|c}{} & & 95 \\
\hline
\end{tabular}




\begin{tabular}{|c|c|c|c|}
\hline 2011 [2] & & & \\
\hline Auto & & Collision & \\
Parking, & & Avoidance & \\
H. & & & \\
Mahmood, & & & 89 \\
$2019[7]$ & $\mathrm{O}\left(\mathrm{n}^{3}\right)$ & & \\
\hline & & Road Surface & \\
Proposed & & Defect Detection, & \\
CBA-LD- & & Severity Detection, & \\
APP & & Accident Prone & \\
Algorithm & $\mathrm{O}(\log \mathrm{n})$ & Zone Marking & 97.69 \\
\hline
\end{tabular}

Henceforth, it is natural to realize that, the proposed method has outperformed the other parallel research works with a significant difference.

Furthermore, in the next section of the work, the research conclusion is presented.

\section{CONCLUSION}

With the growth of the surface transportation systems, the management and monitoring of the road network is gaining its importance. The major setback of further enhancement of any country relies primarily on the intercountry road transportation. It is often observed that the road surface conditions play major role in deciding the safety of the complete transportation system. However, majority of the parallel research outcomes have grossly ignored this factor and primarily focused on the traffic density and other traffic related parameters. Thus, this work identifies the bottlenecks of the parallel research outcomes and have incorporated the road conditions analysis for identification of the road accident possibilities. This work extracts the parameters from the geodetical road surface data and further processes the data and extracts the parameters like Long Slope (Degree), Perpendicular Slope (Degree), Number of Defects, Distance between the Defects $(\mathrm{cm})$, Depth of the defect $(\mathrm{cm})$, Average Width of the $\operatorname{defect}(\mathrm{cm})$ and the total Area of the $\operatorname{defect}\left(\mathrm{cm}^{3}\right)$. Using these parameters, the work identifies the initial thresholds of the values and use the thresholds for determining the regression coefficients. Further, using the regression coefficients, the work again proposes a novel regression model to classify the defects into four major categories and finally maps the severity of the defect categories on the coordinates of the regions. The final outcome of this work is detecting the accident possibilities with $97.69 \%$ with lowest complexity of the model for making the road surface transportations faster and safer.

\section{REFERENCES}

[1] Cai, Y., Wang, H., Chen, X., et al: 'Trajectory-based anomalous behaviour detection for intelligent traffic surveillance', IET Intell. Transp. Syst., 2015, 9, (8), pp. 810-816.

[2] Wang, H., Klaser, A., Schmid, C., et al: 'Action recognition by dense trajectories'. Proc. of IEEE Int. Conf. on Computer Vision and Pattern Recognition, Colorado Springs, CO, USA, 2011, pp. 3169-3176.

[3] Wang, G., Ren, G., Wu, Z., et al: 'A robust, coarse-tofine traffic sign detection method'. Proc. of Int. Joint Conf. on Neural Networks, Dallas, TX, USA, 2013, pp. $1-5$.

[4] Khalid, S., Muhammad, N., Sharif, M.: 'Automatic measurement of the traffic sign with digital segmentation and recognition', IET Intell. Transp. Syst., 2018, 13, (2), pp. 269-279.

[5] Yang, A.Y., Zhou, Z., Balasubramanian, A.G., et al: 'Fast 11-minimization algorithms for robust face recognition', IEEE Trans. Image Process., 2013, 22, pp. 3234-3246.

[6] Dong, Z.S., Zhu, W.X.: 'Homotopy methods based on 10-norm for compressed sensing', IEEE Trans. Neural Netw. Learn. Syst., 2017, 29, pp. 1-15.

[7] Mahmood, Z., Haneef, O., Muhammad, N., et al: 'Towards a fully automated car parking system', IET Intell. Transp. Syst., 2019, 13, pp. 293-302.

[8] Nguyen, H., Cai, C., Chen, F.: 'Automatic classification of traffic incident's severity using machine learning approaches', IET Intell. Transp. Syst., 2017, 11, (10), pp. 615-623.33). 